\title{
THE PRESENCE OF PUTATIVE VIRULENCE DETERMINANTS, TETRACYCLINE AND $\beta$ - LACTAMS RESISTANCE GENES OF Aeromonas SPECIES ISOLATED FROM PET TURTLES AND THEIR ENVIRONMENT
}

\author{
S.H.M.PWimalasena, Gang-Joon Heo* \\ Laboratory of Aquatic Animal Medicine, Veterinary Medical Center and College of Veterinary Medicine, Chungbuk National University, Chung- \\ dae-ro 1, Seowon-gu, Cheongju 28644, Republic of Korea \\ *Corresponding author, E-mail: gjheo@cbu.ac.kr
}

\begin{abstract}
This study aimed to characterize Aeromonas spp. isolated from ten popular species of pet turtles and their environment to evaluate the potential risk of pet turtles as a source of virulence-associated genes, and tetracycline and $\beta$-lactams resistance determinants. Presence of eight virulence genes (ser, aer, exu, lip, fla, ascV, ahyB and gcat), and tetracycline (tetA,

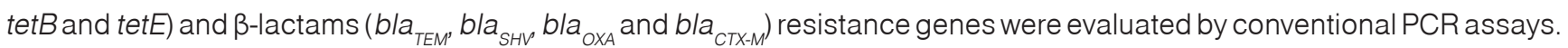
The aerA gene showed the highest frequency of occurrence (92\%), followed by fla (75\%), gcaT (68\%), ahyB (59\%), ser (39\%), lip (37\%) and ascV (25\%) genes. None of the isolates carried amplicon of DNase-associated exu gene. A. hydrophila, A. dharkensis, $A$. veronii and $A$. caviae were carried seven tested virulence genes except for exu while only four virulence genes were detected in A. enteropelogenes. Among the 75 tetracycline-resistant isolates, tetA, tetE and tetB genes were detected in 38,26 and 6 isolates, respectively. Among the tested $\beta$-lactam resistance genes, bla $a_{O X A}$ and $b l a_{T E M}$ genes were detected in $54 \%$ and $36 \%$ of $\beta$-lactam resistant isolates, respectively. No bla $a_{C X-M}$ and $b / a_{S H V}$ genes were detected. Our results indicate that pet turtle-associated aeromonads, exhibiting potential virulence and antimicrobial (tetracycline and $\beta$-lactams) resistance genes, may pose a serious health risk to pet turtle owners, particularly to immunocompromised individuals.
\end{abstract}

Key words: Aeromonasspp.; virulence-associated genes; tetracycline resistance; $\beta$-lactams resistance; pet turtle

\section{Introduction}

Mesophilic aeromonads are ubiquitous bacteria that are a component of the normal microbiota of many aquatic animals such as fish, amphibians, and reptiles (1). They can cause ulcerative stomatitis, pneumonia, dermatitis, and septicemia in reptiles under stressful conditions such as trapping, handling and temperature variations of rearing environment $(2,3)$. Over the years, many studies have been investigated to evaluate the prevalence of Aeromonas species in aquatic animals, mainly food-producing animals $(4,5)$. However, a limited number of

Received: 6 June 2020

Accepted for publication: 28 September 2020 studies evaluating the distribution of aeromonads in pet turtles have been published up to date $(6,7)$.

The pathogenesis of Aeromonas species involves various virulence factors including cytotoxic heat-labile enterotoxin (act), cytotonic heat-labile enterotoxin $(a l t)$ and cytotonic heat-stable enterotoxin (ast), aerolysin (aer), lipase (lip), serine protease (ser), elastase (ahyB), DNase (exu), glycerophospholipid-cholesterol acyltransferase (gcaT), flagellar system (fla) and Type III secretion system (TTSS) effector (asch). These genes encoding virulence factors have been broadly used in determining the potential pathogenicity of Aeromonas species isolated from the environment, foodstuffs, and human clinical samples $(1,8-10)$. 
Recently, antibiotic-resistant aeromonads have been recognized as a serious concern due to their potential health risks to animals and humans (11, 12). Especially, the dissemination of tetracycline and $\beta$-lactams resistance aeromonads in the aquatic environment has been widely documented $(12,13$, 14). Among many tetracycline resistance genes, the tet $E$, tet $A$ and tet $B$ genes were frequently identified from Aeromonas species in the aquatic environment $(12,15,16)$. Aeromonas species can produce numerous $\beta$-lactamases for conferring resistance to $\beta$-lactams. According to isolation sources, the previous studies have shown the different prevalence of genes encoding $\beta$-lactamases in Aeromonas species. In the aquatic environment, the $b l a_{T E M}, b l a_{S H V}$, bla $a_{O X A}$ and $b l a_{C T X-M} \beta$-lactams genes were frequently detected from Aeromonas species (17-19).

These resistance genes containing plasmids and transposons are known as mobile genetic elements that can be transferred horizontally among distantly related lineages. Particularly, The aquatic environment is more favorable for the transmission of resistant bacteria, thus, Aeromonas species as opportunistic pathogens might be dangerous vectors for the spreading of antibiotic resistance genes through the aquatic environment $(18,20)$. Hence, the present study was conducted to determine the occurrence of antimicrobial resistance genes (tetracyclines and $\beta$-lactams) and virulence-associated genes of Aeromonas species isolated from pet turtles and their environment.

\section{Materials and methods}

\section{Bacterial isolates}

One hundred and two Aeromonas species isolates obtained from ten commercially popular pet turtles species (Chinese stripe-necked turtles Ocadia sinensis, yellow belly sliders Trachemys scripta scripta, river cooters Pseudemys concinna concinna, northern Chinese softshell turtles Pelodiscus maackii, western painted turtles Chrysemys picta belli, peninsula cooters Pseudemys peninsularis, African sideneck turtles Pelusios castaneus, common musk turtles Sternotherus odoratus, red belly cooters Pseudemys rubriventris and alligator snapping turtles Macroclemys Temminckil) and their rearing environment was screened to investigate the presence of putative virulence, and $\beta$-lactams and tetracycline resistance genes. These iso- lates have been previously characterized for their antimicrobial susceptibilities, enterotoxin (act, alt and ast) genes and quinolone resistance determinants $(7,21)$.

\section{Detection of antibiotic resistance genes}

Twenty-eight and seventy-five isolates were selected (21) for the detection of $\beta$-lactams and tetracycline resistance determinants, respectively. These isolates were tested by PCR assays to detect the genetic determinants associated with resistance to $\beta$-lactams $\left(\right.$ bla $_{T E M}, b l a_{S H V}, b l a_{O X A}$ and $\left.b l a_{C T X-M}\right)$, and tetracyclines (tet $A$, tetB and tetE). The primer sets used in PCR amplification are summarized in table 1. PCR amplifications were conducted in 20 $\mu \mathrm{L}$ volumes consisting of $10 \mu \mathrm{L}$ of Quick Taq ${ }^{\circledR} \mathrm{HS}$ DyeMix (Toyobo, Japan), $1 \mu \mathrm{L}$ of $10 \mathrm{pmol} / \mu \mathrm{L}$ each primer and $1 \mu \mathrm{L}$ of the template under standard conditions. The PCR products were analyzed by electrophoresis on 2\% (wt/vol) agarose gels. Positive controls were implemented with previously characterized enterobacterial strains that harbored the corresponding genes $(21,22)$.

\section{Detection of virulence-associated genes}

All isolates were subjected to PCR assays to detect the 8 tested virulence genes including ser, aer, exu, lip, fla, ascV, ahyB and gcat. The PCR amplification of the virulence-associated genes was carried out according to the PCR primers and conditions reported previously (Table 1). The PCR mixture of $20 \mu \mathrm{L}$ contained $10 \mu \mathrm{L}$ Quick Taq HS DyeMix (Toyobo, Japan), $7 \mu \mathrm{L}$ PCR water, 1 $\mu \mathrm{L}$ template and $1 \mu \mathrm{L}$ of each primer. The PCR products were examined by electrophoresis on $1.5 \%(\mathrm{~W} / \mathrm{V})$ agarose gel.

\section{Results}

\section{Bacterial isolates}

One hundred and two Aeromonas species isolates were isolated from the feces, skin and rearing environments of pet turtles and identified by biochemical and gyrB sequence analyses. Aeromonas enteropelogenes was the predominant species among the isolates $(52.9 \%)$ followed by $A$. hydrophila (32.4\%), A. dharkensis (5.9\%), A. veronii (4.9\%) and A. caviae (3.9\%) ${ }^{7}$. 
Presence of resistance genes

Among the tested $\beta$-lactam resistance genes, $b l a_{\mathrm{OXA}}$ and $b l a_{\text {TEM }}$ genes were detected in $54 \%$ and $36 \%$ of $\beta$-lactam resistant isolates, respectively. No $b l a_{\text {СТХ-M }}$ and $b l a_{\text {SHV }}$ genes were detected (Table 2). Among the 75 tetracycline-resistant isolates, tet $A$, tetE and tetB genes were detected in 38, 26 and 6 isolates, respectively (Table 3).

Table 1: Oligonucleotide primers and PCR conditions ${ }^{a}$ used to amplify virulence and antibiotic resistance genes of Aeromonas spp.

\begin{tabular}{|c|c|c|c|c|c|}
\hline Gene & Target & Nucleotide Sequence (5'-3') & $\begin{array}{l}\text { Size } \\
\text { (bp) }\end{array}$ & $\begin{array}{c}\text { Annealing } \\
\text { temperature }\left({ }^{\circ} \mathrm{C}\right)\end{array}$ & Reference \\
\hline \multirow[t]{2}{*}{ aerA } & \multirow[t]{2}{*}{ Aerolysin } & F: CTATGGCCTGAGCGAGAAG & \multirow{2}{*}{431} & \multirow{2}{*}{62} & \multirow{2}{*}{30} \\
\hline & & R: CAGTTCCAGTCCCACCACT & & & \\
\hline \multirow[t]{2}{*}{ ser } & \multirow[t]{2}{*}{ Serine protease } & F: ACCGAAGTATTGGGTCAGG & \multirow{2}{*}{350} & \multirow{2}{*}{55} & \multirow{2}{*}{13} \\
\hline & & R: GCTCATGCGTAACTCTGGT & & & \\
\hline \multirow[t]{2}{*}{ fla } & \multirow[t]{2}{*}{ Flagella } & F: CCAACCGTYTGACCTC & \multirow{2}{*}{608} & \multirow{2}{*}{56} & \multirow{2}{*}{36} \\
\hline & & R: MYTGGTTGCGRATGGT & & & \\
\hline \multirow[t]{2}{*}{ ahyB } & \multirow[t]{2}{*}{ Elastase } & F: CACGGTCAAGGAGATCAAC & \multirow{2}{*}{513} & \multirow{2}{*}{58} & \multirow{2}{*}{13} \\
\hline & & R: GCTGGTGTTGGCCAGCAGG & & & \\
\hline \multirow[t]{2}{*}{ lip } & \multirow[t]{2}{*}{ Lipase } & F: ATCTTCTCCGACTGGTTCGG & \multirow{2}{*}{382} & \multirow{2}{*}{62} & \multirow{2}{*}{36} \\
\hline & & R: CCGTGCCAGGACTGGGTCTT & & & \\
\hline \multirow[t]{2}{*}{ exu } & \multirow[t]{2}{*}{ DNase } & F: AGACATGCACAACCTCTTCC & \multirow{2}{*}{323} & \multirow{2}{*}{59} & \multirow{2}{*}{13} \\
\hline & & R: GATTGGTATTGCCTTGCAAG & & & \\
\hline \multirow[t]{2}{*}{ gcat } & $\begin{array}{c}\text { Glycerophospholipid- } \\
\text { cholesterol acyltransferase }\end{array}$ & F: TCCTGGAATCCCAAGTATCAG & 237 & 65 & 12 \\
\hline & & R: GCAGGTTGAACAGCAGTATCT & & & \\
\hline$a s c V$ & Type III Secretion System & F: AGCAGATGAGTATCGACGG & 801 & 58 & 00 \\
\hline & & R: AGGCATTCTCCTGTACCAG & 091 & 50 & 30 \\
\hline$b l a_{\mathrm{TEM}}$ & & F: ATAAAATTCTTGAAGACGAAA & 1080 & 60 & \\
\hline & & R: GACAGTTACCAATGCTTAATC & & & \\
\hline$b l a_{\mathrm{SHV}}$ & & F: TTATCTCCCTGTTAGCCACC & 795 & 60 & \\
\hline & B - lactams resistance & R: GATTTGCTGATTTCGCTCGG & & & 22 \\
\hline$b l a_{\text {СTX-M }}$ & & F: CGCTTTGCGATGTGCAG & 550 & 52 & \\
\hline & & R: ACCGCGATATCGTTGGT & & & \\
\hline$b l a_{\mathrm{OXA}}$ & & F: TCAACTTTCAAGATCGCA & 591 & 60 & \\
\hline & & R: GTGTGTTTAGAATGGTGA & & & \\
\hline tetA & & F: GTAATTCTGAGCACTGTCGC & 1000 & 62 & \\
\hline & & R: CTGCCTGGACAACATTGCTT & & & \\
\hline tetB & Tetronoling reainton & F: CTCAGTATTCCAAGCCTTTG & 400 & 57 & ר? \\
\hline & 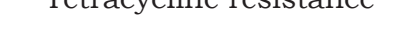 & R: CTAAGCACTTGTCTCCTGTT & & & 24 \\
\hline tetE & & F: GTGATGATGGCACTGGTCAT & 1100 & 62 & \\
\hline & & R: CTCTGCTGTACATCGCTCTT & & & \\
\hline
\end{tabular}

${ }^{a}$ PCR thermocycle conditions for each reaction; initial denaturation of $94{ }^{\circ} \mathrm{C}$ for 2 min followed by a total of 35 cycles of amplification. Each cycle consisted of $94^{\circ} \mathrm{C}$ denaturation for $30 \mathrm{~s}$, annealing for $50 \mathrm{~s}$ and $72{ }^{\circ} \mathrm{C}$ extension for $10 \mathrm{~min}$. 
Table 2: $\beta$-lactams resistance profiles of turtle-associated Aeromonas spp.

\begin{tabular}{|c|c|c|c|}
\hline Isolate & Host ${ }^{a}$ & $\beta$-lactam resistance ${ }^{b}$ & $\begin{array}{l}\beta \text {-lactam resistance } \\
\text { genes }\end{array}$ \\
\hline \multicolumn{4}{|c|}{ Aeromonas caviae } \\
\hline $\mathrm{AD} 14$ & CSN & AMP, AMX, CEP, FOX & $b l a_{T E M}$ \\
\hline AC50 & $\mathrm{RC}$ & AMP, AMX, CEP, CRO, FOX, IMI & $b l a_{O X A}, b l a_{T E M}$ \\
\hline \multicolumn{4}{|c|}{ A. dharkensis } \\
\hline $\mathrm{AD} 17$ & $\mathrm{RC}$ & AMP, AMX, CEP, CRO, FOX, CTX & $b l a_{O X A}, b l a_{T E M}$ \\
\hline AD 18 & $\mathrm{RC}$ & AMP, AMX, CEP, CRO, FOX, CTX & $b l a_{O X A}, b l a_{T E M}$ \\
\hline AD 19 & $\mathrm{RC}$ & AMP, AMX, CEP, CRO, FOX & $b l a_{O X A}$ \\
\hline AD 15 & $\mathrm{CSN}$ & AMP, AMX, CEP, FOX, CTX & $b l a_{O X A}$ \\
\hline \multicolumn{4}{|c|}{ A. enteropelogenes } \\
\hline $\mathrm{AC} 2$ & $\mathrm{RC}$ & AMP, AMX, CEP & $b^{\prime} a_{O X A}$ \\
\hline AC6 & $\mathrm{RC}$ & CEP, FOX & - \\
\hline $\mathrm{AC} 15$ & NCS & AMP, AMX, CEP, FOX & $b l a_{O X A}$ \\
\hline AC30 & $\mathrm{CM}$ & CEP, CTX, ATM & - \\
\hline AC31 & WP & CEP, CTX, ATM & - \\
\hline AC32 & WP & CEP, CTX, ATM & - \\
\hline AC35 & $\mathrm{RC}$ & CEP, CTX, ATM & - \\
\hline $\mathrm{AC} 44$ & YB & AMP, AMX, CRO & $b l a_{T E M}$ \\
\hline $\mathrm{AC} 45$ & $\mathrm{RC}$ & CEP, CRO, ATM & - \\
\hline $\mathrm{AC} 53$ & WP & AMP, AMX, CEP, FOX & $b^{\prime} a_{O X A}$ \\
\hline AV4 & $\mathrm{RC}$ & AMP, AMX, CEP, FOX & $b l a_{O X A}$ \\
\hline AD1 & $\mathrm{CM}$ & AMP, AMX, CEP, FOX & $b l a_{O X A}$ \\
\hline \multicolumn{4}{|c|}{ A. hydrophila } \\
\hline AH1 & $\mathrm{RC}$ & AMP, CEP & - \\
\hline AH11 & CSN & AMP, AMX, CEP, CRO & $b l a_{O X A}, b l a_{T E M}$ \\
\hline AH13 & $\mathrm{CSN}$ & CEP, CRO, FOX, IMI & - \\
\hline AH19 & NCS & AMP, AMX, CEP, CRO & $b l a_{O X A}$ \\
\hline AH20 & NCS & AMP, AMX, CEP & $b l a_{T E M}$ \\
\hline AH22 & YB & $\mathrm{AMP}, \mathrm{AMX}, \mathrm{CEP}$ & - \\
\hline $\mathrm{AH} 23$ & YB & AMP, AMX, CEP, CRO & $b^{\prime} a_{O X A}$ \\
\hline AH25 & $\mathrm{CM}$ & AMP, AMX, CEP, FOX & $b l a_{T E M}$ \\
\hline AD 10 & $\mathrm{AF}$ & AMP, AMX, CEP, FOX & $b l a_{O X A}, b l a_{T E M}$ \\
\hline \multicolumn{4}{|c|}{ A. veronii } \\
\hline AC52 & $\mathrm{SN}$ & AMP, AMX, CEP, FOX & $b l a_{O X A}, b l a_{T E M}$ \\
\hline
\end{tabular}

aHost: $\mathrm{CSN}=$ Chinese stripe-necked turtle, $\mathrm{YB}=$ yellow belly slider, $\mathrm{RC}=$ river cooter, $\mathrm{PC}=$ peninsula cooter, $\mathrm{NCS}=$ northern $\mathrm{Chinese}$ softshell turtle, $\mathrm{CM}=$ common musk turtle, $\mathrm{WP}=$ western painted turtle, $\mathrm{AF}=$ African sideneck turtle, $\mathrm{SN}=$ Alligator snapping turtle.

' $\beta$-lactams resistance: $\mathrm{AMX}=\mathrm{Amoxicillin}(10 \mu \mathrm{g})$, AMP=Ampicillin $(10 \mu \mathrm{g}), \mathrm{CEP}=$ Cephalothin $(30 \mu \mathrm{g}), \mathrm{CRO}=$ Ceftriaxone $(30 \mu \mathrm{g}), \mathrm{FOX}=\mathrm{Cefoxitin}(30$ $\mu \mathrm{g}), \mathrm{CTX}=$ Cefotaxime $(30 \mu \mathrm{g}), \mathrm{IMI}=\mathrm{Imipenem}(10 \mu \mathrm{g})$

Table 3: Distribution of tetracycline resistance genes among tetracycline resistant Aeromonas species isolated from pet turtles and their environment

\begin{tabular}{|c|c|c|c|}
\hline \multirow{2}{*}{ Species } & \multicolumn{3}{|c|}{ Number of positive isolates (Subtotal \%) } \\
\hline & tetA & tetB & tetE \\
\hline Aeromonas enteropelogenes $(n=50)$ & $32(64)$ & - & $8(2)$ \\
\hline A. hydrophila $(n=17)$ & $6(35)$ & - & $12(71)$ \\
\hline A. dharkensis $(n=4)$ & - & $2(50)$ & $3(75)$ \\
\hline A. veronii $(n=3)$ & - & $3(100)$ & $2(66)$ \\
\hline A. caviae $(n=1)$ & - & $1(100)$ & $1(100)$ \\
\hline Total $(\%)(n=75)$ & $38(51)$ & $6(1)$ & $26(35)$ \\
\hline
\end{tabular}


Table 4: Prevalence of virulence-associated genes in Aeromonas species isolates from pet turtles and their environment

\begin{tabular}{|c|c|c|c|c|c|c|c|c|}
\hline \multirow{2}{*}{ Species } & \multicolumn{8}{|c|}{ Number of positive isolates (Subtotal \%) } \\
\hline & aerA & lip & $a h y B$ & ser & exu & fla & gcat & $\operatorname{ascV}$ \\
\hline Aeromonas enteropelogenes $(n=54)$ & $46(85)$ & 0 & $21(39)$ & 0 & 0 & $51(94)$ & $23(43)$ & 0 \\
\hline A. hydrophila $(n=33)$ & $33(100)$ & $30(91)$ & $28(85)$ & $31(94)$ & 0 & $19(58)$ & $33(100)$ & $15(47)$ \\
\hline A. dharkensis $(n=6)$ & $5(83)$ & $3(50)$ & $4(67)$ & $4(67)$ & 0 & $2(33)$ & $6(100)$ & $4(67)$ \\
\hline A. veronii $(n=5)$ & $5(100)$ & $3(60)$ & $5(100)$ & $3(60)$ & 0 & $2(40)$ & $4(80)$ & $3(60)$ \\
\hline A. caviae $(n=4)$ & $4(100)$ & $2(50)$ & $2(50)$ & $2(50)$ & 0 & $3(75)$ & $3(75)$ & $4(100)$ \\
\hline Total $(\%)(n=102)$ & $93(92)$ & $38(37)$ & $60(59)$ & 40 (39) & - & $77(75)$ & $69(68)$ & $26(25)$ \\
\hline
\end{tabular}

\section{Distribution of virulence-associated genes}

The occurrence and frequencies of virulence genes are shown in Table 4. The aerA gene showed the highest frequency of occurrence $(92 \%)$, followed by fla (75\%), gcaT (68\%), ahyB (59\%), ser $(39 \%)$, lip (37\%) and ascV (25\%) genes. None of the isolates carried amplicon of the DNase-associated exu gene.

\section{Discussion}

The Aeromonas spp. under study were multidrug-resistant turtle-associated bacteria which carried quinolone resistance determinants, as well as enterotoxin genes $(7,21)$. The isolates were highly resistant to $\beta$-lactams especially amoxicillin, ampicillin and cephalothin. $\beta$-lactam antibiotics have used for the treatment of Aeromonas infection during the last decade. However, their efficacy has significantly declined due to the production of $\beta$-lactamases by resistant bacterial strains $(14,17$, 23). The Aeromonas spp. are naturally resistant to $\beta$-lactams because of the expression of chromosomal $\beta$-lactamases (24).

In this study, twenty-eight aeromonads isolates were resistant to the more than one $\beta$-lactam antibiotics. Among them, 54\% and 36\% of isolates harbored $b l a_{O X A}$ and $b l a_{T E M}$ genes. Several previous studies have documented the detection of the $b l a_{O X A}$ and $b l a_{T E M}$ genes in Aeromonas isolates recovered from the environment $(14,25)$ and clinical samples (26) and the prevalence of gene detection varies according to the isolation sources. In Korea, a previous study reported that the $b l a_{O X A}$ and $b l a_{T E M}$ genes were detected in 3\% and $100 \%$ of Aeromonas isolates from aquaculture fish [14]. However, a different trend was observed in this study which the $b l a_{O X A}$ and $b l a_{T E M}$ genes were detected in Aeromonas isolates from pet turtles that suggest a wide distribution of $\beta$-lactamase genes in Aeromonas isolates from various sources.

A much higher level of tetracycline resistance was observed amongst aeromonads in our previous study (7) and 78 of tetracycline-resistant isolates were selected to detect their tetracycline resistance determinants (tet $A$, tet $B$ and tetE). A. enteropelogenes and $A$. hydrophila harbored tet $A$ and tet $E$ genes while other Aeromonas species harbored tet $B$ and tetE genes. Previous reports indicate that the tet $A$ and tetE determinants are the predominant tetracycline resistance genes in the aquatic environment $(16,27)$ and both genes code for an efflux pump that eliminates the drug from the cell ${ }^{28}$. The tet $A$, tet $B$ and tetE genes are located on the plasmid as well as tet $A$ in the transposon ( $\operatorname{Tn} 1721)$ and tet $E$ is adjacent to the integrons (15). Han et al. (27) has reported that tetE gene was the predominant tetracycline determinant in Aeromonas spp. isolated from Korean fish farms and aquariums. However, Kim et al. (29) reported that tetA was the most frequent gene in $A$. salmonicida strains isolated from salmonid farms and private aquariums in Korea. The tet $B$ gene was detected at a low frequency, while Jacobs and Chenia. (12) reported a lower prevalence of tetB genes among Aeromonas spp. isolated from the South African aquaculture system.

Detection of virulence encoding genes of Aeromonas spp. have been widely applied for evaluating their potential pathogenicity $(30,31)$. However, the prevalence of virulence-associated genes has rarely been reported in Aeromonas strains from pet turtles (7). In the current study, Aeromonas isolates were found to possess genes aerA, lip, ahyB, ser, fla, gcat and $a s c V$, while genes for DNase (exu) was not identified. Especially, none of A. enteropelogenes isolates harbored lip, ser, exu and $a s c V$ 
genes. Previous studies have revealed that multiple virulence-associated genes are present in Aeromonas isolates and having high heterogeneity in the distribution of virulence-associated genes $(10,30,31)$. The pore-forming aerolysin/hemolysin encoded aer gene was the most prevalent in this study which was detected in $92 \%$ of the total isolates representing all species of the genus. Several studies have reported the high prevalence of the aer gene in clinical and environmental Aeromonas isolates (30, 32).

The three enterotoxins act, alt, and ast have been implicated as major virulence factors in diarrhoeal disease which had been investigated in our previous study (7). However, the presence of these toxins might not be enough for virulence (31). The temperaturestable metalloprotease with elastolytic activity (ahyB) and serine protease (ser) play an important role in the invasiveness and establishment of infection (1). In the current study, the $a h y B$ and ser genes were detected in $59 \%$ and $39 \%$ of isolates, respectively. None of the A. enteropelogenes isolates harbored ser gene. The flagella are important appendages for the initial attachment of bacteria to the gastrointestinal epithelium and involve in the subsequent adherence process and biofilm formation $(33,34)$. The fla gene-encoded polar flagella were common among the Aeromonas isolates from the aquatic environment. The fla gene was detected in $99 \%$ of Aeromonas isolates from diseased eel in Korea (10). The gcaT gene plays a coherent, integrated role in the establishment of pathogenicity of Aeromonas spp. by involving in the regulation and secretion of extracellular glycerophospholipid-cholesterol acyltransferase (13). The gcaT gene was detected in $68 \%$ of Aeromonas isolates.

Lipases play a role as virulence factors by interacting with leukocytes or by disturbing several immune system functions through free fatty acids produced by the lipolytic activity. Extracellular lipases secreted by Aeromonas spp. actively involve in the alteration of the host plasma membrane and thus increase the severity of infection (35). Among Aeromonas strains isolated in the present study, $91 \%$ of $A$. hydrophila, $60 \%$ of $A$. veronii, $50 \%$ of $A$. dharkensis and $50 \%$ of $A$. caviae isolates were found to have lip gene. Several previous studies reported a high prevalence of lip gene among the Aeromonas isolates from the aquatic environment $(10,36)$. Type III secretion system (T3SS) plays a crucial role in hostpathogen interactions by injecting effector toxins directly into the cytosol of host cells (37). The acsV gene encodes the T3SS and which was detected in
$59 \%$ of Aeromonas spp. except for A. enteropelogenes isolates. The presence of $a s c V$ gene was previously detected in $68 \%$ of Aeromonas spp. isolated from diseased farmed fish and farm environment (38). Besides, the high frequency of ascV gene was reported in human clinical isolates (37).

The exu gene is responsible for DNA hydrolysis which was not detected in this study. The absence of exu gene was also reported by Nawaz et al. (13) in $A$. veronii isolated from catfish in the USA. In contrast, the high prevalence of exu gene was observed in Aeromonas spp. isolated from freshwater lakes in Malaysia (39) and diseased eel in South Korea (10). The specificity of the host or environmental source could be the possible reasons for the absence of exu gene in this study.

According to the available literature, this is the first description of these virulence-associated genes in Aeromonas of pet turtle origin. Most of Aeromonas strains isolated from pet turtles and their environment harboring multiple virulenceassociated genes have the potential to be pathogenic. Turtle born aeromonads carrying tetracycline and $\beta$-lactams resistance determinants can disseminate through the environment. Collectively, which may pose a public health risk to pet turtle owners, particularly to immunocompromised individuals.

\section{Acknowledgment}

This study was supported by the Basic Science Research Program through the National Research Foundation of (KNRF) funded by the Ministry of Education (NRF-2015R1D1A1A01060638) in the Republic of Korea.

Authors declare that no any conflict of interest exists.

\section{References}

1. Janda JM, Abbott SL. The genus Aeromonas: taxonomy, pathogenicity, and infection. Clin Microbiol Rev 2010; 23: 35-73. https://doi.org/10.1128/ CMR.00039-09.

2. Kim KT, Kwak D. A case of Aeromonas hydrophila infection due to captivity-induced stress in a spectacled caiman (Caiman crocodilus). J Anim Plant Sci 2013; 23 (6): 1761-3.

3. Chen J, Zhu N, Kong L, Bei Y, Zheng T, Ding $\mathrm{X}, \mathrm{He} Z$. First case of soft shell disease in chinese soft-shelled turtle (Trionyx sinens) associated with Aeromonas sobria-A. veronii complex. Aquaculture 
2013; 406-407, 62-7. https://doi.org/10.1016/j. aquaculture.2013.05.006.

4. Evangelista-Barreto NS, Vieira RH, Carvalho FCT, et al. Aeromonas spp. isolated from oysters (Crassostrea rhizophorea) from a natural oyster bed, Ceará, Brazil. Rev Inst Med Trop São Paulo 2006; 48: 129-33.

5. Shakir Z, Khan S, Sung K, et al. Molecular characterization of fluoroquinolone-resistant Aeromonas spp. isolated from imported shrimp. Appl Environ Microbiol 2012; 78: 8137-41. https://doi. org/10.1128/AEM.02081-12.

6. Lupescu I, Baraitareanu S. Emerging diseases associated with" New companion animals": review in zoonoses transmitted by reptiles. Sci Works Ser C Vet Med 2015; 61: 135-8.

7. Wimalasena SHMP, Shin GW, Hossain S, Heo GJ. Potential enterotoxicity and antimicrobial resistance pattern of Aeromonas species isolated from pet turtles and their environment. J Vet Med Sci 2017; 79: 921-6. https://doi.org/10.1292/jvms.16-0493.

8. Khajanchi BK, Fadl AA, Borchardt MA, et al. Distribution of virulence factors and molecular fingerprinting of Aeromonas species isolates from water and clinical samples: suggestive evidence of water-to-human transmission. Appl Environ Microbiol 2010; 76: 2313-25. https://doi.org/10.1128/ AEM.02535-09.

9. Ottaviani D, Parlani C, Citterio B, et al. Putative virulence properties of Aeromonas strains isolated from food, environmental and clinical sources in Italy: a comparative study. Int $\mathrm{J}$ Food Microbiol 2011; 144: 538-45. https://doi. org/10.1016/j.ijfoodmicro.2010.11.020.

10. Yi SW, You MJ, Cho HS, Lee CS, Kwon JK, Shin GW. Molecular characterization of Aeromonas species isolated from farmed eels (Anguilla japonica). Vet Microbiol 2013; 164: 195-200. https:// doi.org/10.1016/j.vetmic.2013.02.006.

11. Deng YT, Wu Y, Tan AP, et al. Analysis of antimicrobial resistance genes in Aeromonas spp. isolated from cultured freshwater animals in China. Microb Drug Resist 2014; 20: 350-6. https://doi. org/10.1089/mdr.2013.0068.

12. Jacobs L, Chenia HY. Characterization of integrons and tetracycline resistance determinants in Aeromonas spp. isolated from South African aquaculture systems. Int J Food Microbiol 2007; 114: 295-306. https://doi.org/10.1016/j.ijfoodmicro.2006.09.030.

13. Nawaz M, Khan SA, Khan AA, et al. Detection and characterization of virulence genes and integrons in Aeromonas veronii isolated from catfish. Food Microbiol 2010; 27: 327-31. https:// doi.org/10.1016/j.fm.2009.11.007.

14. Yi SW, Chung TH, Joh SJ, Park C, Park BY, Shin GW. High prevalence of bla ${ }_{\text {CTX-M }}$ group genes in Aeromonas dhakensis isolated from aquaculture fish species in South Korea. J Vet Med Sci 2014; 76: 1589-93. https://doi.org/10.1292/jvms.140274.

15. Akinbowale Ol, Peng H, Barton MD. Diversity of tetracycline resistance genes in bacteria from aquaculture sources in Australia. J Appl Microbiol 2007; 103: 2016-25. https://doi.org/10.1111/ j.1365-2672.2007.03445.x.

16. Nawaz M, Sung K, Khan SA, Khan AA, Steele R. Biochemical and molecular characterization of tetracycline-resistant Aeromonas veronii isolates from catfish. Appl Environ Microbiol 2006; 72: 6461-6. https://doi.org/10.1128/AEM.00271-06.

17. Henriques IS, Fonseca F, Alves A, Saavedra MJ, Correia A. Occurrence and diversity of integrons and $\beta$-Lactamase genes among ampicillin-resistant isolates from estuarine waters. Res Microbiol 2006; 157: 938-47. https://doi.org/10.1016/j.resmic.2006.09.003.

18. Maravić A, Skočibušić M, Šamanić I, et al. Aeromonas spp. simultaneously harboring bla(CTX-M-15), bla(SHV-12), bla(PER-1) and bla(FOX-2), in wild-growing mediterranean mussel (Mytilus galloprovincialis) from Adriatic sea, Croatia. Int J Food Microbiol 2013; 166: 301-8. https:/ / doi.org/10.1016/j.ijfoodmicro.2013.07.010.

19. Tacão M, Correia A, Henriques I. Resistance to broad-spectrum antibiotics in aquatic systems: anthropogenic activities modulate the dissemination of blaCTX-M-like genes. Appl Environ Microbiol 2012; 78: 4134-40. https://doi.org/10.1128/ AEM.00359-12.

20. Piotrowska M, Popowska M. The Prevalence of antibiotic resistance genes among Aeromonas species in aquatic environments. Ann Microbiol 2014; 64: 921-34. https://doi.org/10.1007/s13213-0140911-2.

21. Wimalasena SHMP, De Silva BCJ, Hossain S, Pathirana HNKS, Heo GJ. Prevalence and characterization of quinolone resistance genes in Aeromonas species isolated from pet turtle in Korea. J Glob Antimicrob Resist 2017; 11: 34-8 https://doi. org/10.1016/j.jgar.2017.06.001.

22. Chung T, Yi S, Kim B, Kim W, Shin GW. Identification and antibiotic resistance profiling of bacterial isolates from septicaemic soft-shelled turtles 
(Pelodiscus Sinensis). Vet Med 2017; 62: 169-77. https://doi.org/10.17221/65/2016-VETMED.

23. Bhaskar M, Dinoop KP, Mandal J. Characterization of ceftriaxone-resistant Aeromonas spp. isolates from stool samples of both children and adults in southern India. J Health Popul Nutr 2015; 33: e26. https://doi.org/10.1186/s41043-015-0036-7.

24. Figueira V, Vaz-Moreira I, Silva M, Manaia CM. Diversity and antibiotic resistance of Aeromonas spp. in drinking and waste water treatment plants. Water Res 2011; 45: 5599-611. https://doi. org/10.1016/j.watres.2011.08.021.

25. Piotrowska M, Przygodzińska D, Matyjewicz K, Popowska M. Occurrence and variety of $\beta$ lactamase genes among Aeromonas spp. isolated from urban wastewater treatment plant. Front Microbiol 2017; 8: e863 https://doi.org/10.3389/ fmicb.2017.00863.

26. Puah SM, Puthucheary SD, Liew FY, Chua $\mathrm{KH}$. Aeromonas aquariorum clinical isolates: antimicrobial profiles, plasmids and genetic determinants. Int J Antimicrob Agents 2013; 41: 281-4. https:// doi.org/10.1016/j.ijantimicag.2012.11.012.

27. Han JE, Kim JH, Choresca CH, et al. Prevalence of tet gene and complete genome sequencing of tet gene-encoded plasmid (PAHH01) isolated from Aeromonas species in South Korea. J Appl Microbiol 2012; 112: 631-8. https://doi.org/10.1111/j.13652672.2012.05237.x.

28. Chopra I, Roberts M. Tetracycline antibiotics: mode of action, applications, molecular biology, and epidemiology of bacterial resistance. Microbiol Mol Biol Rev 2001; 65: 232-60. https://doi. org/10.1128/MMBR.65.2.232-260.2001.

29. Kim JH, Hwang SY, Son JS, et al. Molecular characterization of tetracycline- and quinolone-resistant Aeromonas salmonicida isolated in Korea. J Vet Sci 2011; 12: 41-8. https://doi.org/10.4142/ jvs.2011.12.1.41.

30. Chacón MR, Figueras MJ, Castro-Escarpulli G, Soler L, Guarro J. Distribution of virulence genes in clinical and environmental isolates of Aeromonas spp. Antonie Van Leeuwenhoek 2003; 84: 269-78.
31. Sha J. Role of various enterotoxins in Aeromonas hydrophila-induced gastroenteritis: Generation of enterotoxin gene-deficient mutants and evaluation of their enterotoxic activity. Infect Immun 2002;70:1924-35. https://doi.org/10.1128/ IAI.70.4.1924-1935.2002.

32. Ghenghesh KS, Ahmed SF, Cappuccinelli $\mathrm{P}$, Klena JD. Genospecies and virulence factors of Aeromonas species in different sources in a north African country. Libyan J Med 2014; 9 (1): e25497. https://doi.org/10.3402/ljm.v9.25497.

33. Kirov SM, Castrisios M, Shaw JG. Aeromonas flagella (polar and lateral) are enterocyte adhesins that contribute to biofilm formation on surfaces. Infect Immun 2004; 72: 1939-45. https:// doi.org/10.1128/IAI.72.4.1939-1945.2004.

34. Umelo E. Identification and molecular characterization of two tandemly located flagellin genes from Aeromonas salmonicida A449. J Bacteriol 1997; 179: 5292-9.

35. Pemberton JM, Kidd SP, Schmidt R. Secreted enzymes of Aeromonas. FEMS Microbiol Lett 1997; 152: 1-10. https://doi. org/10.1111/j.1574-6968.1997.tb10401.x.

36. Sen K, Rodgers M. Distribution of six virulence factors in Aeromonas species isolated from US drinking water utilities: A PCR identification. J Appl Microbiol 2004; 97: 1077-86. https://doi. org/10.1111/j.1365-2672.2004.02398.x.

37. Vilches S, Urgell C, Merino S, et al. Complete type III secretion system of a mesophilic Aeromonas hydrophila strain. Appl Environ Microbiol 2004; 70: 6914-9. https://doi.org/10.1128/ AEM.70.11.6914-6919.2004.

38. Carvalho-Castro GA, Lopes CO, Leal CAG, Cardoso PG, Leite RC, Figueiredo HCP. Detection of type III secretion system genes in Aeromonas hydrophila and their relationship with virulence in nile tilapia. Vet Microbiol 2010; 144: 371-6. https://doi.org/10.1016/j.vetmic.2010.01.021.

39. Khor WC, Puah SM. Tan JAMA, Puthucheary $\mathrm{S}$, Chua KH. Phenotypic and genetic diversity of Aeromonas species isolated from fresh water lakes in Malaysia. PLOS ONE 2015; 10 (12): e0145933. https://doi.org/10.1371/journal.pone.0145933. 


\title{
PRISOTNOST DETERMINANT ZA DOLOČITEV DOMNEVNE VIRULENCE TER GENOV ZA OD- PORNOST NA TETRACIKLIN IN $\beta$-LAKTAM VRST Aeromonas IZOLIRANIH IZ LJUBITELJSKIH VRST ŽELV IN IZ NJIHOVEGA OKOLJA
}

\author{
S.H.M.PWimalasena, G-J.Heo
}

Izvleček: Namen študije je bil določiti bakterije Aeromonasspp., izolirane iz desetih priljubljenih vrsthišnih želvin njihovega okolja, znamenom ocenjevanja potencialnega tveganje hišnih želv kot vira genov, povezanih z virulenco, ter determinante odpornosti proti tetraciklinom in $\beta$-laktamom. Prisotnost osmih virulentnih genov (ser, aer, exu, lip, fla, ascV, ahyB in gcat) ter genov za odpornost na tetracikline (tetA, tetB in tetE) in $\beta$-laktame $\left(b^{\prime} a_{T E M^{\prime}}, b_{S H V} b l a_{O X A}\right.$ in bla $\left.a_{C T X-M}\right)$ je bila ocenjena s konvencionalnimi testi PCR. Najbolj pogostje bil Gen aerA (92\%), slediliso geni fla (75\%), gcaT (68\%), ahyB (59\%), ser (39\%), lip (37\%) in ascV(25\%). Nobeden od izolatov ni imel pomnoženega gena exu, povezanegazDNAzo. A. hydrophila, $A$. dharkensis, A. veroniiin $A$. caviaesovsebovali sedem testiranih genov virulence, razen exu, medtem ko so biliv $A$. enteropelogenih odkriti le štirje virulenčni geni. Med 75 izolati, odpornimi na tetracikline, so bili geni tetA, tetE in tetBodkriti 38,26 oziroma 6 izolatih. Med preizkušenimi geni za odpornost proti

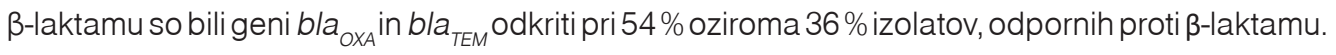

$\checkmark$ nobenem vzorcu nista bila zaznana gena bla $a_{C T X M}$ in bla ${ }_{S H V}$ Rezultati študije kažejo, da bakterije Aeromonas spp. iz hišnih želv lahko imajo potencialne virulenčne gene in gene za odpornost proti tetraciklinu in $\beta$-laktamom, in lahko potencialno ogrožajo zdravje lastnikov hišnih želv, zlasti imunsko oslabljenih posameznikov.

Ključne besede: Aeromonas spp.; geni povezani z virulenco; odpornost na tetracikline; rezistenca na $\beta$-laktami; ljubiteljske vrste želv 